\title{
Comparing Notes: Recording and Criticism
}

\section{Christopher Dingle ${ }^{1}$}

In London on my way to Italy I had some talks in the Savile billiardsroom with Robin Legge, the musical critic of the Daily Telegraph ... [who] said suddenly: 'Why don't you write me an article about the gramophone? Let me have it as soon as you can.' That suggestion from Robin Legge after he had just potted the brown made that moment one of the most decisive moments in my life. ${ }^{2}$

It would be absurd now to suggest that recordings were not a legitimate subject for music criticism. For some genres, they are arguably the primary focus of reviews and comment, whether these appear in newspapers, magazines, journals, online or are broadcast. At the time Compton Mackenzie conceived The Gramophone in September

\footnotetext{
${ }^{1}$ I am profoundly grateful to Sophie Redfern for her ferreting on my behalf for various sources that feed into this chapter and some insightful comments on it. It should be noted at the outset that, as a member of the review panel for BBC Music Magazine since 1994, I am a participant in, as well as an observer of, aspects of this particular field.

${ }^{2}$ Compton Mackenzie, My Life and Times: Octave Five 1915-1923 (London: Chatto \& Windus, 1966), p. 232.
} 
1922, the notion of reviewing records was far from established. ${ }^{3}$ Forty-five years had passed since Thomas Edison's invention of the phonograph in 1877 and commercial recordings had started to be produced in significant quantities in the 1890s. Moreover, the years immediately after the end of the First World War saw a substantial expansion of activity for the record companies. However, according to Mackenzie's perception in his entertaining autobiography, Robin Legge (Daily Telegraph) and Percy Scholes (the Observer), 'were the only musical critics who had as yet recognized that such an instrument as the gramophone existed, and occasionally noticed some new record'. Nor was this situation peculiar to Britain, for record reviews were equally scarce if not non-existent, in US newspapers and those from continental Europe. Just as recording has fundamentally transformed how music in general is composed, performed, heard, mediated and understood, it has also specifically affected criticism in profound ways. The criticism of recordings constitutes a prime exemplar of what Mark Katz refers to as the concept of the 'phonograph effect', that is, the ways in which the ability to capture and reproduce sound influences musical life. ${ }^{5}$ It is not merely that there is something additional to review, that recordings have encouraged and facilitated engagement with new genres and repertoires, or even that recording has changed approaches to performance, but

\footnotetext{
${ }^{3}$ The Gramophone became plain Gramophone in June 1969. This chapter uses the title relevant to the period under discussion.

${ }^{4}$ Mackenzie, My Life and Times, Octave Five, p. 232.

${ }^{5}$ Mark Katz, Capturing Sound: How Technology has Changed Music (Berkeley and Los Angeles: University of California Press, 2004), p. 3.
} 
also that they have stimulated changes of method, language and understanding for music criticism itself.

This chapter starts with consideration of some ways in which the criticism of recordings is distinct from that of live performance, then moves onto a broadly chronological exploration of the emergence of recordings as an object for criticism. The London Times is a thread through this discussion, acting as a case study of changing attitudes within a key newspaper, while other titles naturally also feature along the way, notably The Gramophone. In the latter part of the chapter, two controversies act as a catalyst for discussion of issues and challenges specific to reviewing recordings.

\section{Differences Between Live and Record Reviewing}

In some respects, the criticism of recordings is simply an adaptation of concert reviewing with its twin elements of chronicle and judgement. There is clear overlap between a live concert and an audio recording for the reviewer, but there are also significant differences of approach and intention that are set out in table 13.1.

\begin{tabular}{c|c} 
Concerts & Recordings \\
\hline Ephemeral event experienced once & Artefact heard multiple times \\
Immediate impression of an historical & Considered view of performance that \\
Performers (and audience) can be & can still be heard \\
observed & The performance is acousmatic
\end{tabular}


Evaluation of a unique event

Contributing to reputation from multiple events
Performance can be placed in direct comparison with others

Strong element of consumer advice for specific product in addition to general reputation

\section{Table 13.1: Key Traits of Concert and Record Reviewing}

In terms of chronicling, whereas concert reviews recount what has happened at an event, the record review is more akin to the preview, informing the reader of new opportunities for experiencing music. With recordings, the element of critique is of a specific performance that can, in principle, be shared by all readers, rather than one ephemeral exemplar: concert reviews refer to the past, record reviews to an eternal present. As a consequence, the review helps to establish a reputation for the recording itself, so that reference is made to Glenn Gould's 1955 recording of Bach's Goldberg Variations as distinct from his 1981 version or those by numerous other performers. This has exaggerated the trend towards concentrating on discussion of performance that had already begun with the canon formation of the nineteenth century.

Thanks to recordings and broadcasts, critics of both live and recorded performances can now assume that readers are familiar with much music or could easily become so. Moreover, because record reviews discuss artefacts that continue to be sold, compilations in book form continue their usefulness to the reader. When reading what Newman or Cardus wrote about a particular performance of Sibelius or Wagner, it is possible to critique their writing and to consider whether their view of the music differs from current perceptions. However, their judgements about the 
performance can, at best, only provide clues as to whether they would be shared today. By contrast, Gramophone now has a monthly 'Classics Reconsidered' feature in which two current critics discuss a notable historical recording in the context of its original review.

The ability to listen more than once to a recording has significant practical implications for the critic. To start with, deadlines tend to be appreciably more generous with recordings, being at least a week or two rather than a day or even just an hour or so for concerts. Whereas there is an imperative to publish reviews of concerts and gigs as soon as possible after the event, it is still worthwhile printing a perceptive review of a recording several months after its release date. Crucially, it is not necessary to reside in the metropolis to access the music, significantly broadening the potential pool of critics. For the first few years of The Gramophone's existence, Compton Mackenzie's was resident on the tiny island of Jethou, in the Channel Isles, communication while there being exclusively via small boat.

The fact that records could be listened to anywhere represented vastly increased access to music for all, with a concurrent enlarging of the potential readership for reviews. This, allied to the fact that there was now a choice of competing performances for purchase has meant that, from the outset, it has usually been imperative for record critics not just to report and critique, but also recommend from among the alternatives. The critic needs to cater both for those on a limited budgetseeking advice on which is the recording buy and those wanting insight on whether to add a newcomer to those already on their shelf. As early as 1935 , the 
American Music Lover, ${ }^{6}$ used a system of star ratings for popular records and The Gramophone did the same for jazz and swing from 1936. Star ratings were adopted in numerous pop, rock and jazz magazines, but it was not until the late 1980s that their use became widespread both in classical magazines and reviews in broadsheet newspapers.

One consequence of recordings entering critical discourse was that a new generation of non-specialist critics appeared at the very time that, with varying degrees of success, newspaper criticism had been attempting to professionalize. As noted in The Times in 1929: 'One of the chief functions of the gramophone and its records is to supply the semi-musical with a library. Few of us can read satisfactorily from a score; we need to hear the notes as well as to see them. ${ }^{7}$ Compton Mackenzie was open about the limitations of his own musical training and that, at least initially, The Gramophone was written by enthusiasts, though it is worth remembering he was a professional writer with numerous books to his name by the time The Gramophone was launched. Regardless, his manner of record reviewing raises eyebrows:

My quarterly review of records running to about six thousand words would have been an impossible task if I had not learnt to listen to records being played while I was writing a book ... Without it I should never have been able to maintain my rate of production. I would know at once if [my secretary]

\footnotetext{
${ }^{6}$ The successor, in essence, of Phonograph Monthly Review (founded 1926), and the brief Music Lovers' Guide. The title eventually became American Record Guide.

${ }^{7}$ Unsigned, ‘The Musician's Gramophone. Bach, Brahms Beethoven', The Times (2 April 1929), 14.
} 
Nellie Boyte had put on the wrong side of a record and was listening critically all the while. Yet I was able nevertheless to concentrate on my writing. ${ }^{8}$

It is worth remembering at this point that, save for those with a dutiful secretary to assist, listening to recordings was punctuated every four or five minutes by the need to change the sides of the record. More sustained listening only became possible from 1948 with the approximately 23 minutes per side of the long player (LP).

The comparative possibilities of record reviewing were apparent early on. A December 1922 review of a recording of Beethoven's 'Emperor' Concerto, for instance, characterized soloist Frederic Lamond's approach as being 'Beethoven as seen through another personality, albeit one very much in sympathy with, and appreciative of, his art' before contrasting it with that of Harold Bauer's, who had appeared in several concerts in November and who 'gives us the essence of Beethoven's music as a universal rather than a personal experience'. ${ }^{9}$ It was natural, and part of the raison d'être of The Gramophone to parse the differences between rival recordings of works, such as this 1937 round-up of available versions of Debussy's Prélude à l'après-midi d'un faune: 'The Albert Hall Orchestra's flute seems more matter-of-fact: the sun is not so cordial. Philadelphia's spaciously speaking flute seems to be mirroring itself in a lake ... For the full-scale sweep and swirl, the effulgence of the whole garden's perfume, the Philadelphia; for perhaps an

${ }^{8}$ Compton Mackenzie, My Life and Times: Octave Six 1923-1930 (London: Chatto \& Windus, 1967), p. 15.

${ }^{9}$ Unsigned [From A Correspondent], 'New Gramophone Records. Piano

Reproductions', The Times (1 December 1922), 10. 
even subtler fragrance, at moments, the Straram' ${ }^{10}$ While such comparisons are now a natural part of musical discourse, and were not entirely absent before the advent of recording, they marked a profound shift in critical sensibility. Even as late as 1940, the critic in The Times observed that 'Comparisons are said to be odious, and criticism generally avoids them. Gramophone connoisseurs, however, do not, and one of their favourite occupations is to compare readings and recordings'. ${ }^{11}$

While most of the differences between concert and record reviewing noted in table 13.1 are self-evident, the acousmatic aspect of recordings, the ability to hear music without musicians present, is now such a pervasive and natural part of everyday life that it is easy to overlook. The solid artefact of a recording paradoxically enables the music to become completely disembodied and portable. As if to compensate for the lack of a visible performer, early writing and criticism of recordings often referred to the gramophone as an instrument. This habit may initially have reflected scientific interest in Edison's invention, but mutated as recordings began to proliferate at the turn of the twentieth century to suggest that having a gramophone in the house was equivalent to possessing a piano.

\section{Early Coverage}

While it was not until the 1920s that reviewing records became commonplace, the phenomenon of recording was certainly discussed. News of Edison's invention drew

\footnotetext{
${ }^{10}$ W.R.A [William Robert Anderson], 'Second Reviews', The Gramophone (May 1937), 525 .

${ }^{11}$ Unsigned, 'The Gramophone. A Tallis Fantasia', The Times (6 August 1940), 6.
} 
significant comment on both sides of the Atlantic, featuring widely in the US press in November 1877. These reports were picked up in the UK by the Liverpool Mercury at the end of the month, spreading to London and elsewhere by January $1878 .{ }^{12}$ A flurry of articles followed demonstrations of the phonograph in London at the Crystal Palace and at the Royal United Services Institution in the spring of 1878. Recording then largely drops from view for about a decade, reflecting in part the fact that Edison put his invention to one side while developing the electric light. Even after the advent of his improved phonograph and Emile Berliner's gramophone, discussion of recording before the turn of the twentieth century was primarily limited to sporadic reports of exhibitions, scientific lectures and business application of these talking machines, with shortcomings often being to the fore: 'The phonograph, ingenious as it is, cannot at present be regarded as anything more than a philosophical toy ... not one of the useful purposes of every-day life has been subserved by this remarkable machine'. ${ }^{13}$ Mention of music in this period was generally restricted to noting the use of national anthems or similar patriotic songs in demonstrations.

Even once recordings of music, notably classical music, began to proliferate in the 1900s, with artists such as Adelina Patti, Nelly Melba and Enrico Caruso being prominent in the catalogue of the Gramophone and Typewriter Company, the notion of reviewing the records themselves simply did not occur. Rather, the earliest exemplars of recordings being reviewed are where they appear as part of a 'gramophone concert'. These events, which were covered by newspapers from as

\footnotetext{
${ }^{12}$ Liverpool was the principal port for trade with the US.

${ }^{13}$ Unsigned, 'Recent Developments in Acoustical Science', The Times (19 August 1878), 4.
} 
early as $1904,{ }^{14}$ were organized by the nascent record companies to display the technology and the latest recordings:

The result was a considerable surprise to many of those present, the programme including reproductions of the voices of many of the most eminent singers of today ... The long programme of new records contained much admirable singing admirably reproduced ... the records vary in quality, but all are good, and some of them are delightful. ${ }^{15}$

On occasion the recordings were accompanied by a live piano or even an orchestra. ${ }^{16}$ Whatever the nature of the event, at least as much of the comment centred on the quality of the reproduction achieved, a natural concern given not only that the technology was still in its infancy, but also that advertisements lauded the reality of the recordings. A concert at the Savoy Hotel in London went so far as to place the voices of Clara Butt and Kennerley Rumford on record alongside their live performances of the same repertoire, resulting in critical insight of potential value to current-day scholars:

Had we not just listened to the singers viva voce we should certainly have declared the gramophone's a wonderful imitation ... But with Mme Clara

\footnotetext{
${ }^{14}$ See, for instance, Unsigned, 'The Gramophone', The Times (25 March 1904), 5.

${ }^{15}$ Unsigned, 'Opera on the Gramophone', The Times (21 May 1906), 4.

${ }^{16}$ See, for instance, Unsigned, 'A Gramophone Concert', The Times (2 May 1909),
} 12. 
Butt's tones still ringing in our ears it was impossible not to notice that it had introduced a faint nasal tinge into her lower notes and tightened some of her higher notes so as to give the impression that her throat was not fully open. ... An odd little weakness on the instrument's part is its inability to pronounce sibilants - it lisps. ${ }^{17}$

Such comments are corroborated by a review from the end of acoustic era that also notes a distorting affect on the contralto voice: 'Miss Leila Megane makes a success in two of Mr. Bantock's "Songs of Egypt," avoiding in these that "scoop" into which the lower contralto notes are sometimes perverted by the gramophone' ${ }^{18}$

\section{Critical Concerns}

The quality of the reproduction was often the primary factor in judging the success of otherwise of a particular disc. In fact, it was not unusual for shortcomings to be attributed to the technology rather than the musicians, as in this review of Thibaud and Cortot's record of Franck's violin sonata: 'There are occasional passages in the later [sic] where the recording makes the E string playing uncertain'. ${ }^{19}$ The improvement in quality by 1940 is clear from a review of Vaughan Williams's The

\footnotetext{
${ }^{17}$ Unsigned, 'A Gramophone Concert', The Times (5 October 1909), 11.

${ }^{18}$ Unsigned, 'New Gramophone Records. Mozart's Fourth Violin Concerto', The

Times (13 April 1925), 8.

${ }^{19}$ Unsigned, 'Gramophone Notes. Additions to Chamber Music', The Times (17

February 1925), 12.
} 
Lark Ascending: 'The recording (by Decca) is conspicuously good since one can hear the pull of the bow on the string and the tone is both pure and full even on the highest notes - only the triangle cuts a poor figure! ${ }^{20}$

It should be remembered that another recording medium was prevalent in the first three decades of the twentieth century: player pianos. Until the mid-1920s, the poor quality and difficult studio conditions of audio recording meant that solo piano repertoire was far more likely to be committed to piano roll than discs or cylinders, along with transcriptions of chamber and orchestral works. ${ }^{21}$ The overwhelming majority of these remain unknown to modern listeners as they have not been realized for audio recordings. Improvements in audio quality even before electric recording dmeant that demand was already on the decline, so that the inclusion of a Player Piano supplement with The Gramophone in June 1924 lasted only until March 1925.

A sign of the increasing acceptance of audio recording in the years after the First World War is reflected in the fact that two elements of the service for the burial of the Unknown Warrior at Westminster Abbey on Armistice Day 1920 were captured: Kipling's 'Recessional' and 'Abide with me'. Intriguingly, the Columbia Gramophone Company used an 'electrical process', five years earlier than commercial electrical recordings were generally available (albeit by a different

\footnotetext{
${ }^{20}$ Unsigned, 'The Gramophone. Music Round the Map', The Times (1 June 1940), 4.

${ }^{21}$ For more on this in relation to French repertoire, see Christopher Dingle, 'Players and Pianos: An Overview of Early Recorded Resources for the French Piano Repertoire', in Scott McCarrey and Lesley Wright (eds.), Perspectives on the Performance of French Piano Music (Farnham: Ashgate, 2014), pp. 125-48.
} 
technology). ${ }^{22}$ The years after the First World War also saw signs of how recordings enabled artists to have international profiles, making them familiar figures before stepping foot in a country. Reviewing Jascha Heifetz's first appearance in Britain at the Queen's Hall, London, on Wednesday 3 May 1920, the critic in The Times noted that the violinist 'brought a huge audience ... because his fame had preceded him in a series of gramophone records ... [which] instantly convinced people that here was something exceptional in the art of violin playing'. ${ }^{23}$ The critic went on to bemoan the fact that Heifetz did not play any substantive works, missing the opportunity to build on what was already known through the records. By the time of Amelita Galli-Curci's first London performances, not only had recordings ensured that her fame preceded her, leading to sell-out recitals at the Royal Albert Hall, but they also raised expectations that, in the view of The Times critic, were met only partly:

It is possible that the artist who, like Mme. Galli-Curci, is blest with the perfect recording voice and style may find that it brings moments of embarrassment. Only the unblemished record goes out from the shop, and it a creates a standard to which she must live up on the concert platform ...

22 There are several reports, notably Unsigned, 'Gramophone Records by Electricity. Memorial of Unknown Warrior's Funeral', The Times (8 December 1920), 14.

${ }^{23}$ Unsigned, 'A New Violinist. Jascha Heifetz at Queen's Hall', The Times (Thursday 6 May 1920), 14. 
Generally what one admires about Mme. Galli-Curci is that she can do so much with a voice confined to one colour, and that a pale one. ${ }^{24}$

Such observations reflect a keen awareness of which types of performer were most effective without the visual stimuli of live performance and within the restricted soundworld of the gramophone:

Cortot seems to understand the limitations of the gramophone better than any other solo pianist, or is it that the natural crispness of his style is sympathetic to the medium? Paderewski, in recent records of favourite things from Chopin ... seems to forget the impersonality of the disk. [sic] Many players partly enact their music, so that for the perfect appreciation of what we hear we need to see the movement of head and hands. Certainly, his rendering of the familiar A flat Prelude comes disjointedly in the gramophone's disembodied echo, and exhibits the liberties a great artist takes with his score rather than the qualities which justify him in taking them. ${ }^{25}$

Years later, Neville Cardus reflected that for certain artists, even those whose recordings are revered, the extraordinary impact of their live performances died with them: 'I would implore everybody who listens to Kathleen Ferrier on record - no

${ }^{24}$ Unsigned, 'Mme. Galli-Curci. First Concert at The Albert Hall', The Times (13 October 1924), 12.

${ }^{25}$ Unsigned, ‘The Musician’s Gramophone. Beethoven, Schumann, Mendelssohn', The Times (12 July 1929), 12. 
matter how much they are charmed by her voice - to remember that they are experiencing only 50 per cent of her'. He goes on to cite Karajan as someone where much less was lost. ${ }^{26}$

The potential threat posed by recordings to broader musicality, even culture in general, has been a periodic refrain from various composers and musicians so it is little surprise to find critics occupied by similar concerns at an early stage:

The gramophone is listened to just because it is a gramophone; as the cinematograph is watched just because it is a cinematograph. In both cases mechanical ingenuity is taking the place of art as a source of amusement: and it is doing this because we have learnt to be merely passive enjoyers of art and have lost all knowledge of the true delight of art, which can come only to those who practise it. ${ }^{27}$

If this 1910 reflection is prophetic of, for instance, Britten's 1964 Aspen speech declaring the loudspeaker an enemy of music and outside true musical experience, ${ }^{28}$ others saw recordings as a catalyst for greater attentiveness:

${ }^{26}$ Robin Daniels, Conversations with Cardus (London: Victor Gollancz, 1976), pp. $230-31$.

${ }^{27}$ Unsigned, 'Mechanical Amusement', The Times (7 September 1910), 9.

${ }^{28}$ Benjamin Britten, 'On Receiving the First Aspen Award', speech given on 31 July 1964 at Aspen Music Festival, Colorado. The speech is reproduced in full on the festival website: www.aspenmusicfestival.com/benjamin-britten (accessed 30 September 2017). 
There is an excellent gramophone record of Kreisler and Zimbalist playing together Bach's concerto for two violins. Their differences of detail are clearly distinguishable, and to appreciate it is a more complete lesson in phrasing than the most thorough verbal analysis could be. It compels the hearer to active participation in the art, and that is listening as distinct from hearing. ${ }^{29}$

Such comment from 1921 demonstrates that, while Compton Mackenzie's characterization of the paucity of interest in records among the press in 1922 was broadly true, Legge and Scholes were not actually the only UK critics to have shown an engagement with records. The Musical Times began a monthly 'Gramophone Notes' feature in January 1921, over six years before the German equivalent, Die Musik, began its 'Mechanische Musik' section in October 1927. Written by 'Discus', 'Gramophone Notes' opened with confirmation that consumer advice was a strong impetus, referring to a letter from a reader who 'warns me in a friendly way that what gramophone users require is candid information as to what records are satisfactory from a musical point of view' ${ }^{30}$ Similarly, by February 1922, The Times had recognized the need for regular critical engagement with the gramophone:

A great number of people buy gramophones without having any very clear idea of what use to make of them, beyond a vague sense that it will be nice to

\footnotetext{
${ }^{29}$ Unsigned, 'The Future of the Gramophone. Converted Musicians', The Times (23 July 1921), 8 .

30 'Discus', 'Gramophone Notes', Musical Times (1 January 1921), 40-41. [40-42]
} 
'turn it on' in a dull moment. It is thought that an occasional short article here may suggest some of the more definite uses. ${ }^{31}$

Periodic reviews began to appear a fortnight later, several months before Mackenzie's fateful game of billiards:

Among the more recent acquisitions of the gramophone repertory the records of Elizabethan madrigals, ballets, and other choral songs made by the English Singers for "His Master's Voice" seem peculiarly valuable and interesting ... these records are very good music, good in the sense that they are music originally made for people of ordinary musical capacity to enjoy, sung by a first-rate combination of singers, who have on the whole been extraordinarily successful in transferring their performance to the disc. ${ }^{32}$

Nonetheless, if Mackenzie's memory of events typically brushes over the nuances, the launch of The Gramophone remains a significant moment in record reviewing.

Mackenzie, whose own exploits would be barely credible in one of his many novels (including work in military intelligence and helping found the Scottish National Party while being the sole resident of Jethou in the Channel Islands), had only recently discovered the potential of recordings and combined his customary

${ }^{31}$ Unsigned, 'Gramophone Music. Encouragement of Close Listening', The Times (23 February 1922), 10.

${ }^{32}$ Unsigned, 'Madrigals on the Gramophone. Records by the English Singers', The Times (9 March 1922), 10. 
energy with the zeal of the convert. The article for The Telegraph requested by Robin Legge in the Savile Club billiards room appeared on 22 September 1922, but an encouraging letter from Legge the day before prompted more ambitious plans: 'I began to wonder if it might not be a good idea to bring out a monthly magazine devoted to the gramophone. I recall that at about half-past five on the afternoon of this notion's occurring to me I saw the planet Venus over Monte Solaro.'33 To some, including Mackenzie's brother-in-law, Christopher Stone, the timing was less auspicious as the advent of the wireless appeared likely to render the gramophone obsolete. Stone was eventually prevailed upon to invest in the magazine, which duly launched in April 1923. ${ }^{34}$ Mackenzie himself was initially dismissive of the wireless, stating in the opening editorial of the first edition: 'We shall have nothing to do with Wireless in these columns. Our policy will be to encourage the recording companies to build up for generations to come a great library of good music. ${ }^{, 35}$ A meeting with John Reith, the Managing Director of the recently formed British Broadcasting Company, ${ }^{36}$ was the catalyst for a change of heart by Mackenzie prompted by their shared desire to promote 'good music' ${ }^{37}$ Indeed, in 1929 he set-up Vox, a sister

\footnotetext{
${ }^{33}$ Mackenzie, My Life and Times: Octave Five, p. 235.

${ }^{34}$ Ibid., pp. 235 and 250.

${ }^{35}$ Compton Mackenzie, 'Prologue', The Gramophone Vol. 1/1 (1923), p.1.

36 The British Broadcasting Company was formally dissolved on 31 December 1926 and the British Broadcasting Corporation was created on 1 January 1927 by Crown Charter, Reith's new designation being Director General.

${ }^{37}$ Mackenzie, My Life and Times: Octave Five, pp. 251-2.
} 
magazine to The Gramophone devoted to radio criticism, but it received the support neither of the radio manufacturers nor the Radio Times and only lasted a few issues. ${ }^{38}$

The potential educational benefits widely perceived in recording prompted strong debate about taste and the quality of the music being disseminated. Some bemoaned the dangers of recordings spreading poor music, by which was generally meant dance and jazz records:

But how good is the thing which we now enjoy? Musical pleasure of a kind is undoubtedly now more widely distributed than ever, but discrimination is still rare. Europe, without Prohibition, imports musical drugs from America. ${ }^{39}$

The prevalent view among commentators, though, was an enthusiastic embrace of the gramophone's potential for educating the public and providing access to 'good' music. In the early years, it was usual for the first few paragraphs of a review in The Gramophone to be a descriptive introduction to the music in the manner of a programme note even for commonplace repertoire (it should be remembered that recordings were not accompanied by any booklet or sleeve notes at this time). As Percy Scholes wrote to Compton Mackenzie, 'it seems admirable that fine music should no longer remain the private preserve of a tiny body of initiates' ${ }^{40}$ Similarly, Axel B. Johnson's editorials for The Phonograph Monthly Review (October 1926-

\footnotetext{
${ }^{38}$ Mackenzie, My Life and Times: Octave Six, pp. 178, 197-8, 204 and 206.

${ }^{39}$ Unsigned, 'Ubiquitous Music. Jazz and the Gramophone', The Times (31 July 1926), 10.

${ }^{40}$ Mackenzie, My Life and Times: Octave Six, p. 20.
} 
March 1932) are littered with references to 'the cause of music' and 'the movement' ${ }^{41}$ Others were more zealous, a headline in The Times in July 1921 proclaiming with relish “"Popular” Records Now Unpopular'. ${ }^{42}$ The article, signed 'A Correspondent' observed that 'With the technical improvement [in the gramophone] there has come an artistic improvement, and with the latter there has come a further improvement in popular taste'. Purporting to draw on information from an industry insider, the article goes on to note that 'far better business was being done with records of good pieces of music' and that 'Wagner, Stravinsky, and the Russian composers seemed to be most in favour at present ${ }^{, 43}$ In a similar vein, Smith C. McGregor wrote an editorial article for Etude, a US magazine, seeking to provide advice for the uninitiated in starting a record collection, explaining that:

'Unbalanced' record collections are a common failing among phonograph owners. You probably know several people who have expensive phonographs and plenty of records, but who do not seem to get full enjoyment from them. There are a great many such record collections, especially outside the cities; for country people, as a rule, do not have the opportunity to attend concerts and otherwise become familiar with the best music. And unless good music

\footnotetext{
${ }^{41}$ See, for instance, the editorial for the third issue: The Phonograph Monthly Review, Vol. 1/3 (December 1926), 99.

${ }^{42}$ Unsigned [From A Correspondent], 'The Gramophone Habit. "Popular” Records Now Unpopular', The Times (22 July 1921), 7.

${ }^{43}$ Ibid.
} 
predominates in a collection, the owner is not going to receive lasting pleasure from it. ${ }^{44}$

The antipathy towards jazz and other 'light' music was commonplace between the wars. As late as April 1937 Compton Mackenzie railed in The Gramophone: 'Most of the light music and dance music of the time is the work of pickpockets, not artists, or rather of nasty little boys who steal the sticky sweets of other nasty little boys. ${ }^{45}$ If Mackenzie wore his prejudices on his sleeve, one unsigned article in The Times on the direction of music marks an early exemplar of the argument against the 'great man' view of history (though possibly out of a wish to undermine claims of greatness for contemporary figures), disputing the importance of individuals in influencing taste:

One has to consider that music of one sort or another enters the lives of millions where formerly it affected hundreds ... All these new conditions are creating new tendencies, which are far more powerful than the experiments of a group of composers, however clever they may be. Some of these tendencies

\footnotetext{
${ }^{44}$ Smith C. McGregor, 'Twelve Foundation Stones for your Record Collection', The
} Etude (May 1921), 339. The complete run of Etude (1883-1957), compiled by Dr Pam Dennis, is available at: https://digitalcommons.gardner-webb.edu/etude/ (accessed 7 March 2018).

${ }^{45}$ Compton Mackenzie, 'Editorial', The Gramophone (April 1937), 460 - 62 [459 62]. 
threaten disaster, others hold out hope of a wider artistic life, but all strike hard at the doctrine of the divine right. ${ }^{46}$

Despite Mackenzie's antipathy, The Gramophone included reviews of popular genres (light, swing, jazz and even rock) with varying regularity until the 1990s. Similarly, dance and popular records were regularly featured from the outset of record reviewing in newspapers, including The Times, and with no hint of disparagement: ${ }^{47}$

The popularity of gramophone records of dance music is increasing rapidly, and during the last month a large number of admirably played selections of this kind have been issued by the Columbia, the Gramophone, and the Æolian companies. $^{48}$

In terms of The Gramophone, just as the income from popular artists has often subsidized recordings of substantial classical works, Mackenzie came to recognize the economic imperative of including this music. In this respect, it is likely that he was persuaded by Cecil Pollard, who, having left a firm of accountants for The Gramophone in 1925, was essentially responsible for the day-to-day running of the

${ }^{46}$ Unsigned, 'Modern Tendencies in Music. The Composer's Estimate', The Times (17 July 1920).

${ }^{47}$ For more on this, see Simon Frith's chapter 'Writing about Popular Music' in this book.

${ }^{48}$ Unsigned, 'New Gramophone Records. Beethoven's Ninth Symphony', The Times (28 March 1924), 12. 
magazine until his death four decades later, negotiating numerous financial and logistical challenges. While popular genres were a vital part of The Gramophone's business model, as Simon Frith has observed, Melody Maker (lauched 1926) and Rhythm (launch 1927) were far more influential for British collectors of jazz records. ${ }^{49}$ Similarly, as Mark Racz observes in chapter twenty-four of this book, Downbeat and Metronome emerged in the 1930s from the numerous fanzines. Since recordings were the principal means for many of hearing jazz, the limited timespan of the 78rpm disc, as mediated through the observations of critics, came to define the initial understanding of what constituted a genre actually founded on much longer improvisational forms. A generation later, pop and, especially rock, came to be delineated first by the 7-inch single, then by the span of an LP. In the words of Frith, 'to be a rock critic was to be a record critic'. ${ }^{50}$ The advent of rock criticism spawned new magazines, notably Rolling Stone, though in the UK Melody Maker reinvented itself for the new market.

\section{The Times: A Case Study}

Back in the 1920s, newspapers were still working out how to tackle recordings. From August 1924 record reviews in The Times were given a specific column, 'Gramophone Notes', which generally appeared monthly. The column was eclectic,

${ }^{49}$ Simon Frith, 'Going Critical: Writing About Recordings', in Nicholas Cook, Eric Clarke, Daniel Leech-Wilkinson and John Rink (eds), The Cambridge Companion to Recorded Music (Cambridge: Cambridge University Press, 2009), p. 278.

${ }^{50}$ Ibid., p. 267. 
featuring not just classical and dance music, but also Morris and other folk music, the Aldershot Tatoo and even an early keep fit record in the form of a pair of discs released to 'to teach listeners "physical jerks" and exercise'. ${ }^{51}$ While critical comments appeared, the column was primarily an elegant litany informing readers of what had been released. A qualitative change occurred in April 1928 with the appearance of a new column, initially called 'The Gramophone', then, from August the same year, 'The Musician's Gramophone'. It is a title reflecting the retrenchment of snobbery, for it was concerned exclusively with classical music. The column considered just three or four discs in detail, providing substantive comment on the performances and giving catalogue numbers, first of all at the bottom, then, from February 1929, incorporated into the body of the review. As with its predecessor, 'The Musician's Gramophone' was broadly monthly, though not every month, and it was occasionally more frequent. The length was similarly variable, generally being 600 to 800 words, but it could be over 1200 words or barely 300 . This was record reviewing much as it is still practised today: 'Kreisler, great player that he is, constructs his tone, constructs his rhythm; Szigeti's come from him. Therefore his rendering of [Brahms's] Concerto ... less uniformly magisterial than Kreisler's, has a supple rhythmical vitality which brings us very near the secret of the constructive evolution of the work. Kreisler is rectilinear, Szigeti yielding' ${ }^{52}$

${ }^{51}$ Unsigned, 'Gramophone Notes. The Aldershot Tatoo', The Times (29 July 1926), 10.

${ }^{52}$ Unsigned, 'The Musician’s Gramophone. Stravinsky, Borodin, Ravel, Brahms', The Times (21 May 1929), 10. 
As might be expected, the Second World War brought changes, with the length of reviews in what was by now 'The Gramophone' column dropping to less than 350 words in the early years of the war. Although clearly an oasis from dwelling on contemporary events, a periodic refrain is the potential for recordings to compensate for the reduced opportunities to experience live performance: 'There will be no opera at all in London this May ... Opera lovers may console themselves with complete recordings of quite a number of the operas we usually hear in the summer' ${ }^{53}$ Similarly, just over a year later, there is understandable yearning: 'It is a reminder of happier times to put on the new records of Verdi's Otello that have come to us from America during May, the very time when we should normally be going to Covent Garden to hear it.'54 'The Gramophone' column varied from monthly appearances to flurries of activity, such as in the summer of 1941, when it appeared on 5, 6, 15, 26 and 28 August then on 3 September. Thanks to continued paper rationing, the length rarely went much beyond 500 words even in the decade after the war.

With the advent of long-playing records, record reviews from March 1951 simply appeared under bespoke headers, losing 'The Gramophone' as an identifying feature. It returned as a title in the mid-1950s. The column broadly doubled in length and moved from appearing once or twice monthly, usually on a Tuesday, to almost every week on Saturdays. From June 1956 it periodically featured a round-up of jazz records, initially 'from a correspondent' and becoming in December 1962 'from a music critic', a reflection of the paper's move towards having a bespoke jazz critic. It

\footnotetext{
${ }^{53}$ Unsigned, 'The Gramophone. Operatic Fare', The Times (27 April 1940), 4.

${ }^{54}$ Unsigned, 'The Gramophone. Verdi's “Otello”, , The Times (1 July 1941), 6.
} 
might have been thought that popular music would gain similar acceptance following William Mann's landmark positive appraisal of The Beatles in December $1963,{ }^{55}$ but it was only with the release of Sgt. Pepper's Lonely Hearts Club Band in 1967 that an album was reviewed on release rather than discussed in retrospect. ${ }^{56}$ With the following year's The Beatles (commonly known as The White Album), Mann's informed admiration prompted him to open with the declaration that 'The most important musical event of the year occurs today' and conclude without any hint of sarcasm that 'no other living composer has achieved so much this year' ${ }^{57}$ Nonetheless, Mann's reviews of the later albums by The Beatles were distinct from the 'Records' column (as 'The Gramophone' had become by the late 1960s), which remained devoted to classical music with periodic jazz input. Spring 1970 marked the addition of folk and rock criticism with two writers from Melody Maker, Karl Dallas and Richard Williams joining the paper. An early statement of intent, and confirmation that there was no collective view among the critics, came with that year's Critics' Choice feature. Paul McCartney's first solo album McCartney, nestled among Wagner, Debussy, Tavener and Henze in Mann's selections, supported by the claim that 'If the Beatles are finished, history will surely regard McCartney as their

${ }^{55}$ Unsigned ['From Our Music Critic' (William Mann)], 'What Songs the Beatles Sang', The Times (27 December 1963), 4.

${ }^{56}$ William Mann, 'The Beatles Revive Hopes of Progress in Pop Music', The Times (29 May 1967), 9.

${ }^{57}$ William Mann, 'The New Beatles Album', The Times (22 November 1968), 9. 
musical genius, the writer of their most progressive and viable music. ${ }^{58}$ Williams, by contrast, stated provocatively that the second album from Canadian-American group The Band 'has more good songs than Lennon and McCartney have ever written' 59 In February 1974, The Times moved to a 'Records of the month' feature, essentially collating what had previously been weekly columns, variously by one of Alan Blyth, Joan Chissell, Max Harrison, John Higgins William Mann or Stanley Sadie, onto a single monthly page. For the remainder of the decade, this was almost exclusively classical in orientation. Contrary to common perceptions, when jazz and rock versions of the feature started to appear in October 1982, this was essentially additional coverage, appearing in different weeks from the classical records. Weekly reviews returned in the autumn of 1986, but this time with classical, rock and jazz all represented - the essence of the format that has endured to the present, with the periodic addition of other genres such as world and country music.

\section{Changing the Landscape}

The more established status given to rock and jazz from this point on may have been influenced by a new UK broadsheet, The Independent, which had dedicated sections for each genre, and the appearance of new magazines such as $Q$ and Uncut also impacted on the priorities of newspaper record reviewing. Although the number of

${ }^{58}$ William Mann, 'Critics' choice: records of the year', The Times (28 November 1970), 19.

${ }^{59}$ Richard Williams, 'Critics' choice: records of the year', The Times (28 November 1970), 19. 
jazz and, especially, rock discs being reviewed grew significantly, this was not generally at the expense of classical coverage. Rather, the number of recordings reviewed grew overall. Regardless, space for reviews was always an issue. As with concerts, there are more recordings released each month than even dedicated magazines can accommodate. From the start, Gramophone included round-up features traversing several recordings alongside the reviews dedicated to individual releases. The pressure has also applied to newspapers. Interviewed by Jennifer Skellington, Paul Griffiths recalled: 'There was a time when I had to do a lot of little record reviews [for The Times], certainly in the late 1980s ... I think all newspapers find this a problem, that it's very difficult to give adequate space to recordings because there's so many coming out' ${ }^{60}$ The challenge for editors in the face of the substantial volume of recordings released is persistent. In recent years, this has led to developments such as BBC Music Magazine including two pages of 'brief notes', where the disc in question is discussed in a mere $25-30$ words. This reviewing equivalent of a Haiku serves its purpose in terms of at least informing readers that a release exists with some indication of its merits or otherwise. From the perspective of the artists and record companies, any review is better than no review, though it is increasingly striking that record reviews of any genre are relatively brief in newspapers whereas book reviews have tended to retain their length.

${ }^{60}$ Jennifer Skellington, 'Transforming Music Criticism? An Examination of Changes in Music Journalism in the English Broadsheet Press from 1981 to 1991', PhD thesis, Oxford Brookes University (2010), 428. 
As Symes has noted, the evidence for whether record reviews actually influence sales, for good or ill, is contentious, at best. ${ }^{61}$ Anecdotally, the press officer for one leading classical record label was emphatic that the only discernible spike in sales came after a disc was featured on BBC Radio 3's Record Review programme. ${ }^{62}$ Aside from the fact that this may have been flattering talk for an undoubtedly influential individual, this does not mean that reviews in magazines have no influence on sales. A radio programme is generally heard at a single, specific time and date, whereas a magazine may be bought and read at any time during the month of its issue, or even quite some time later.

This raises the question of who is writing the reviews and who is reading them. In the early days it may have been true, as Katz claims, that women bought the phonographs, ${ }^{63}$ but Symes states with some justification that 'those who write for record magazines are mostly male, as are their readers' ${ }^{64}$ and Frith similarly observes that record collecting and the associated review-dominated magazines are a 'man's world' ${ }^{65}$ Certainly Gramophone retained the air of its origins in the Savile Club, of male-dominated affluent exclusivity, both perceived and real, for much of the twentieth century. In reality it was never a male only preserve, with Faith Mackenzie

${ }^{61}$ Colin Symes, Setting the Record Straight: A Material History of Classical Recording (Middletown, CT: Wesleyan University Press, 2004), p. 205.

${ }^{62}$ In a conversation with Andrew McGregor, presenter of Record Review, and myself at the 2016 BBC Music Magazine Awards.

${ }^{63}$ Katz, Capturing Sound, pp. 57-8.

${ }^{64}$ Symes, Setting the Record Straight, p. 177.

${ }^{65}$ Simon Frith, 'Going critical', p. 276. 
(F sharp) contributing from the first issue and Joan Chissell another prominent writer, but these were the exceptions that proved the rule. Changes in printing methods in the late 1980s saw a raft of new challengers to Gramophone, such as CD Review and Classic FM magazine. Perhaps most significant, though, was BBC Music Magazine, which despite association with the national broadcaster, avoided any sense of the old boy network through an openness to new writers and, especially, a far better gender balance. For instance, at editorial level, its founding editor, Fiona Maddocks, created a team where eight of twelve editorial staff were women, with senior roles in subsequent years being filled by figures such as Helen Wallace, Harriet Smith, Claire Wrathall, Amanda Holloway and Rebecca Franks to name but a few. While jazz and world music have largely fallen by the wayside in Gramophone, they still feature in the pages of $B B C$ Music Magazine, even if the content is primarily oriented towards classical music. In this respect it broadly reflects the mix of music on BBC Radio 3. That may be unsurprising, but it is remarkable nevertheless that a magazine that is putatively about music, without any qualifier, on behalf of an organization as allencompassing as the $\mathrm{BBC}$, is not concerned with the music genres the corporation broadcasts on its other radio stations.

Even more so than newspapers, the landscape of magazines featuring record reviewing is littered with short-lived titles. Gramophone is uncommon not only in enduring but also in managing to outlast the title's association with the technology of the time. ${ }^{66}$ As Symes observes, changes in recording technology have tended to

\footnotetext{
${ }^{66}$ American Record Guide is another, though it ceased publication between 1972 and
} 1976. 
prompt new magazines named after the latest format. ${ }^{67}$ For instance, in tandem with its golden anniversary, Gramophone launched the shortlived Cassettes \& Cartridges, while the advent of compact discs spawned Digital Audio (later CD Review) and Classic CD. Similarly, BBC Radio 3's Record Review programme became $C D$ Review in September 1998, a title that became increasingly untenable in the face of SACDs, Blu-Ray audio, downloads and streaming. However, it appears to have been the unexpected revival of vinyl that prompted a reversion to Record Review at the beginning of 2016. In this context, it is striking that the musical associations of longlasting titles in France, Diapason (launched 1956), and the US, Fanfare (launched 1977), both pre-date the recording era. It is also notable that the two principal classically-oriented survivors of the proliferation of UK magazines in the early 1990s are not named after a recording format, but established broadcast brands, Classic FM Magazine and BBC Music Magazine.

In the mid-1980s, following over a decade of reports and false dawns, a new dimension became possible for the criticism of recordings with the advent of home video. There were confident predictions in some quarters that this would replace audio recording. Releases started to appear in 1982, just a year before the launch of the compact disc, but it was not until April 1986 that Gramophone began reviewing them. While cassettes and discs of operas and concerts, as well as documentaries, ensured that video reviewing became a significant strand in the classical sphere, it has remained a relatively incidental aspect of rock criticism.

Critical Scandals

${ }^{67}$ Symes, Setting the Record Straight, p. 162. 
The late 1980s and 1990s saw the marketing of some classical artists in the manner of the pop sphere. The release of Nigel Kennedy's 1989 recording of Vivaldi's The Four Seasons set the ball rolling, followed soon after by The Three Tenors' success following their appearance at the Italia 90 football World Cup. From the other side came recordings of 'classical' works by Paul McCartney, notably Liverpool Oratorio in 1991. Such releases inevitably posed challenges for reviewers. With extensive publicity cultivating a narrative that these releases were breaking the stuffy world of classical music, any caveats about the quality of the performances of The Three Tenors or Nigel Kennedy, or the music of Liverpool Oratorio risked being taken as evidence that classical reviewers were high minded and elitist. This narrative reached its high (or low) point with the release of Vanessa Mae's album The Violin Player, with associated singles, by the pop arm of EMI. Taking the sexualized marketing pioneered by Offra Harnoy the previous decade several steps further, Mae was packaged for the pop market. The promotional team of Mae and EMI protested over the refusal on principle of the classical press, notably Gramophone and BBC Music Magazine, to carry reviews. This shunning of a young artist trying to engage a new audience for classical music appeared to epitomize the snobbishness of the classical press, and is even cited as such by scholars such as Colin Symes. ${ }^{68}$ While some critics were indeed sceptical, this was, in fact, an artificially constructed controversy as the records in question were released as 'pop' products and not sent to classical critics. When EMI classical released Mae's The Classical Album in 1996, Gramophone and BBC Music Magazine both reviewed it.

\footnotetext{
${ }^{68}$ Symes, Setting the Record Straight, p. 201, n. 25.
} 
A scandal a decade later was potentially more damaging for it struck at a fundamental and necessary assumption made a priori by any record reviewer. Since the advent of editing in the late 1940s, it has been known that many recorded performances are essentially artificial constructs. This may be dropping-in certain moments where infelicities occurred, but can extend in extreme cases to the entirety being an assemblage of moments, like an audio jigsaw. Even supposedly live recordings are routinely touched-up, either to cover intrusive audience noise or obvious errors in the performance, a prominent example of the latter being Horowitz's 1965 comeback recital at Carnegie Hall, where some minor slips magically evaporated when an LP of the concert was released by CBS. ${ }^{69}$ Nonetheless, it is assumed that the performances on a disc are by the named artists. This was fundamentally undermined when a stream of CDs from the pianist Joyce Hatto started to appear on the newly-formed Concert Artist label.

Discs from Hatto had appeared several decades before on the Saga label, but, according to interviews she gave shortly before her death and the publicity provided by the label, her activities had long been confined to the studio on account of the cancer that was now in its final stages. The performances on the recordings were spectacular and came with fulsome tributes from Hatto's concert-giving days by figures such as Britten, Cortot, Hindemith, Richter, Rubinstein, Tippett and Vaughan Williams. Combined with the emotive back story, it seemed a harshly overlooked exceptional talent had finally been recognized in her dying days thanks to her loving husband capturing her heroic feats of pianism made under the shadow of terminal illness. With over 90 discs, encompassing swathes of Mozart, Beethoven, Schubert,

\footnotetext{
${ }^{69}$ The unedited recital was eventually released by Sony in 2003 .
} 
Chopin, Schumann, Liszt, Rachmaninov, the Chopin-Godowsky studies, Prokofiev and even Messiaen, it is little wonder that Jeremy Nicholas described her in a Gramophone appreciation as 'one of the greatest pianists I have ever heard' ${ }^{70}$ Similarly, reviewing the set of Messiaen's Vingt regards sur l'enfant-Jésus, Bryce Morrison purred that 'Her playing recreates Messiaen's vision with a fervour and a generosity unknown to even her finest competitors ... she achieves a musical honesty and integrity that resists all compromise. ${ }^{, 71}$

Unfortunately, almost without exception, the performances on the discs were those of other pianists. Her husband, William Barrington-Coupe, had simply taken and remixed existing recordings, altering the sound in a manner akin to changing a wine's bouquet. For instance, the Messiaen performance was actually the recording by Paul Kim made for the Centaur label with the piano made to sound closer and a change in resonance. When the fraud was exposed by Gramophone, aided by Pristine Audio, some were quick to heap derision on the likes of Nicholas and Morrison, and question the integrity of the entire basis of reviewing if experts could not detect such a fake. While they may regret their hyperbole, they were simply taken-in by a conman preying on their understandable desire to believe a ruthlessly exploited human interest story with a consequent loss of critical distance. ${ }^{72}$

\footnotetext{
70 Jeremy Nicholas, 'Joyce Hatto: Piano Dreams', Gramophone (March 2006), 67.

${ }^{71}$ Bryce Morrison, 'Messiaen: Vingt regards sur l'enfant-Jésus', Gramophone (December 2006), 92-3.

${ }^{72}$ In a phone conversation shortly before the fraud was exposed, Barrington-Coupe told me that he was convinced the effort of completing the Messiaen recording had shortened his wife's life. A few minutes later, he stated that she had also recorded
} 
Beyond the 'Objective' Microphone

In a sense, the Hatto fraud exploited the potential for certain recorded performances to move beyond the normal bounds of criticism and expose the fallacy of the objective comparison of recorded artefacts. Every live performance is exceptional, in that it is an irrecoverable experience unique to those in attendance. By fixing sound, recording suggests the possibility of a particular performance being contemplated free from the possibly distorting effect of the event and listened to purely for the music. The context of some live performances means that the usual critical faculties are, if not suspended, then of reduced relevance. One clear example would be the 'Ode to Freedom' performance of Beethoven's Symphony No. 9 conducted by Leonard Bernstein in Berlin on 24 December 1989 just after the Berlin Wall came down. ${ }^{73}$ The same applies to certain recordings that are either historic (rather than just historical) or have an exceptional hinterland. Alongside the disc released of the Bernstein concert, instances might include Bruno Walter's live recording of Mahler's ninth symphony made with the Vienna Philharmonic Orchestra in January 1938 just weeks before the Anschluss, or Dinu Lipatti's last recital, given while severely ill. Once the

\footnotetext{
Messiaen's even larger cycle Catalogue d'oiseaux. With Morrison's glowing review of the Vingt regards, he presumably perceived a further opportunity to profit from Kim's complete Messiaen set.

${ }^{73}$ Bernstein had the chorus replace 'freude' (joy) with 'freiheit' (freedom) for the hastily arranged concert, which featured performers from East and West Germany, the US, USSR, UK and France.
} 
circumstances are known, it would be pointless including such recordings in a blind listening for their significance does not reside in the sound alone. Other recordings acquire historic status either through the participation or imprimatur of the composer, the significance of certain performers or simply being the first of a particular work or repertoire. In the case of Pablo Casals and the Bach solo cello suites, his recording might even be considered an ur-performance, in that it arguably created a performing tradition. There are also, of course, plenty of recordings that are regarded as historic simply for the excellence of the performance. Except that, even here, it can become unclear whether what is heard is coloured by the reputation, the classic status, possibly considered through rose-tinted glasses.

The point is that the criticism of recordings is, and has always been, inherently canon-forming, not just in terms of repertoire, but also specific performances of any given piece. This can be seen as early as Percy Scholes's First Book of the Gramophone Record which, along with its sequel, explicitly set-out to assist the novice in building a library of key works from Byrd to the present (i.e. 1924) in reliable recordings. ${ }^{74}$ It is an approach subsequently adopted by books such as The Record Guide ${ }^{75}$ The Stereo Record Guide (the forerunner to The Penguin Guide to

\footnotetext{
${ }^{74}$ Percy A. Scholes, The First Book of the Gramophone Record (London: Oxford University Press, 1924); The Second Book of the Gramophone Record (London:

Oxford University Press, 1925).

${ }^{75}$ Edward Sackville-West and Desmond Shawe-Taylor, The Record Guide (London: Collins, 1951).
} 
Recorded Classical Music), ${ }^{76}$ The Rolling Stone Record Guide ${ }^{77}$ and The Penguin

Guide to $\mathrm{Jazz}^{78}$ (to name but a few). The explicit use of recordings cited as benchmarks has been a regular feature of record reviewing from its earliest days, but it has become increasingly tempered by the realities of an ever-expanding catalogue. Whether in the pages of Gramophone or one of the book-length guides to recordings, it has long been recognized that, even if a single recommendation is required, there may be additional important performances that suit different needs. The everincreasing number of recordings for even relatively unusual repertoire means that it is increasingly rare for the long-running 'Building a Library' feature on BBC Radio 3's Record Review to include all the currently available recordings for the work in question, and certainly not all those ever made. For the jazz critic, recent years have seen the canon of a given artist's recordings made more complex not only by increasingly prevalent issues of performances captured for radio broadcast, but also numerous alternate takes to those originally released.

As Mark Katz has observed, recording has made musical sound something tangible, reified through the products in which it is captured and the processes involved in playing them. ${ }^{79}$ That remains true, though the rise of downloads and streaming has reintroduced an element of its former ephemerality, not just in terms of the lack of a physical artefact, but also the transitory nature of streaming in particular.

\footnotetext{
${ }^{76}$ Edward Greenfield, Ivan March, Robert Layton and Denis Stevens, The Stereo Record Guide, 9 vols. (Blackpool: Long Playing Record Library, 1960-74).

${ }^{77}$ Later The Rolling Stone Album Guide. It was published between 1979 and 2004.

${ }^{78}$ First published in 1992.

${ }^{79}$ Mark Katz, Capturing Sound, pp. 9-10.
} 
These new media question the notion of the recording as a solid, collectible, permanent artefact. While there is no reason why such new formats and media for hearing music should not be the subject of critical attention, they pose challenges that are, as yet, unresolved. It is not just that music critics themselves are used to dealing with discs, but that many of the operating practices of the music industry that has grown up in the era of recordings are also built around the production and marketing of physical formats. It is striking that, especially for classical music, discs rather than downloads or streaming overwhelmingly remain the predominant subject of reviews, not just in physical magazines and newspapers, but also online journals and blogs. Whereas there is no single authoritative recorded performance for most classical music, since the LP, the album has effectively acted as the urtext in pop and rock, the fundamental source, against which live performance is compared and judged. The unexpected revival of vinyl demonstrates that a traditional readership still exists, while formats such as audio-only blu-ray can accommodate the entirety of Wagner's Ring on a single disc. However, consumers are now increasingly purchasing tracks rather than albums, fundamentally changing the relationship between what is reviewed and what readers may actually hear. Nearly a century after the advent of The Gramophone, engagement with recorded music increasingly resembles the fragmentary nature of the acoustic era with its emphasis on individual songs, movements and excerpts. Despite the extraordinary technological advances and vast back catalogues, the work of record critics from all genres is far from done. 